CATHERINE BENOÎT

\title{
SAINT MARTIN'S CHANGE OF POLITICAL STATUS: INSCRIBING BORDERS AND IMMIGRATION LAWS ONTO GEOGRAPHICAL SPACE
}

Anthropologists often analyze globalization as the circulation of goods, people, and ideas that triggers the decrease in nation-state prerogatives and the opening of nation states' borders. In such an analysis, migrations are transnational: people move back and forth between their home country and the host country. Economic and demographic change in St. Martin seems to be a model for the usual scholarly approach to study globalization. ${ }^{1}$ As for the circulation of goods and capital, the economic growth of St. Martin as an offshore financial center and a free port has been due to the movement of untaxed capital for the development of tourism. Where the circulation of people is concerned, up until recently no visa was required for Caribbean citizens, and the absence of a border between the French and the Dutch sides ensured the movement of people from the Caribbean, Asia, and Europe - who make up nearly 80 percent of the total population - between the two parts of the island. The recent migrations of these people succeeded the migrations of St. Martiners themselves who, from the late nineteenth century until the 1960s, moved to other Caribbean islands or the east coast of the United States either seasonally or permanently. Thus residents of St. Martin have family networks that cover several continents and which can be characterized as transnational. Finally, with regard to the circulation of ideas, English is the mother tongue of St. Martiners, while French and Dutch are the official languages used by the governments. Most residents are multilingual and speak English, French, Spanish, and Haitian Creole. The change in the institutional status of the two parts of the island toward total independence from their respective regional

1. This article was translated from French by Hanneke Teunissen.

I use "St. Martin" to designate the whole of the island, "Saint Martin" for the French part, and "Sint Maarten" for the Dutch side. The term "Saint Martinois" refers to those families living on Saint Martin for several generations, "Sint Maarteners" to people on Sint Maarten, and "St. Martiners" includes everyone. I use the term "residents" for the entire population, including foreigners. For a map of the island, see Figure 1.

New West Indian Guide / Nieuwe West-Indische Gids vol. 82 no. 3 \& 4 (2008):211-235 


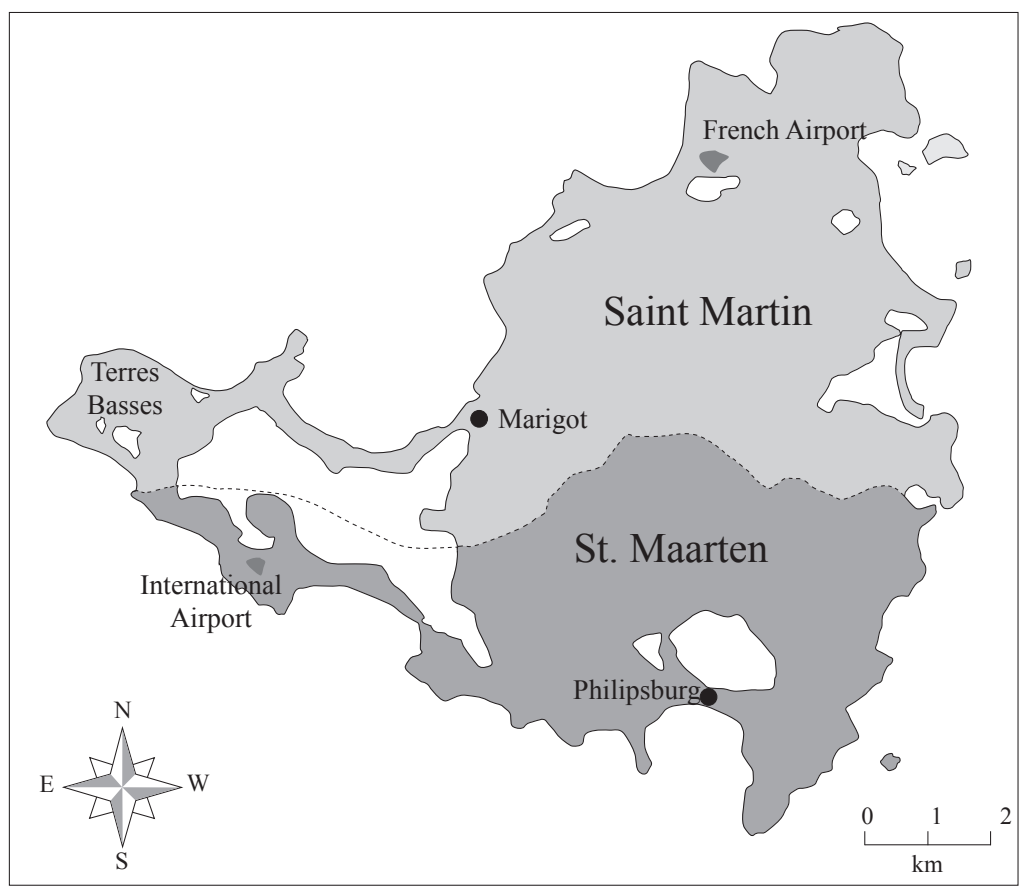

Figure 1. Map of St. Martin

metropoles, Guadeloupe and Curaçao, and a less restricting relationship with France and the Netherlands appear to be the political culmination of economic, demographic, and cultural flows.

In reality, only very specific categories of people and goods may move freely to and throughout the island. The poorest migrants who move to St. Martin do so at a high price: they live in a highly precarious legal, social, and financial situation. These residents, most of them without residency documents, earn less than the legal minimum wage and live in unhealthy housing conditions. They cannot leave the island for fear of not being able to return; they move around the island with difficulty for fear of being deported. Their mobility is the opposite to that of tourists, residents of European origin, and investors, who enjoy the benefits of duty-free shops and tax breaks on their personal and company incomes.

A second anthropological approach to globalization articulates the movement and the enclosing of populations, the development of international institutions or multinationals, and the reinforcement of certain prerogatives of the nation-state. The globe has not become smaller, it has been reorganized into a hierarchical unity of unequal spaces (Heyman 2004). In the anthropology of borders, which has until recently focused on the study of transborder communities, the analysis has shifted to the political definition of the bor- 
ders of contemporary states, and studies have shown how the borders of the most prosperous zones are being strengthened. ${ }^{2}$ Examples of these borders are the wall at the Mexico-U.S. border, the minefields on the eastern border of Europe, and the wire fences around the Spanish enclaves of Ceuta and Melilla in Morocco. However, borders are also represented by restrictive legislation on the entry and stay of foreigners.

In this article, I examine, above all, the articulation between Saint Martin's institutional change and the production of a political space characterized by the legal and spatial redefinition of the island's borders. A process of territorialization accompanies the creation of the overseas collectivity of Saint Martin, causing the island's borders to be closed to foreigners from the Caribbean and the presence of the French state to be reinforced. ${ }^{3}$ Furthermore this article introduces two aspects of Caribbean migration that are infrequently dealt with. I bring to light the existence of intra-Caribbean migratory movements, in contrast to most studies that focus on migration to the European and North American continents, and describe the political and legal barriers restricting these migratory movements, which the concept of transnationalism has in part helped to mask (Puri 2003).

\section{The ECONOMiC And Demographic Evolution of St. MARTin}

In the referendum of December 7, 2003 on the status change of the overseas departments of Guadeloupe and Martinique, Saint Martin, a commune of Guadeloupe, opted to separate from Guadeloupe both administratively and politically, and to increase its autonomy in relation to the French metropole. In February 2007, Saint Martin became an overseas collectivity (COM, Collectivité d'outre-mer) administered by a territorial counsel elected by the population. ${ }^{4}$ Sint Maarten is following a similar evolutionary path. In a series of referendums between 2000 and 2005, the islands of the Federation

2. Wilson \& Hastings 1998, Vila 2003, Cunningham 2004, Cunningham \& Heyman 2004.

3. The following analysis is based on several stays on Saint Martin since 1994 which were dedicated to the therapy management of people living with HIV or sickle cell anemia, and to the change in institutional status. I would like to thank the anonymous reviewers of this journal for their suggestions and advice, as well as Franck Bardinet and Claire Rodier for their feedback, and Marie Duflo for her attentive and painstaking reading of the analysis of immigration laws in overseas France. I would not have been able to draw the map of Saint Martin without the assistance of Frank Fulchiero at Connecticut College.

4. St. Barthelemy, formerly a commune of Guadeloupe, is engaged in the same process. Legally, the two COMs are governed by the Loi Organique (2007-223) which states the application of the Constitution and the Loi Ordinaire (2007-224), both dating from February 21,2007 . They fall under the authority of a prefect delegated to the prefect of Guadeloupe. 
of the Netherlands Antilles, consisting of Curaçao, the seat of the federal government, Bonaire, Saba, St. Eustatius, and Sint Maarten voted to change their status. The Netherlands Antilles will cease to exist as a federation. Each island will have a one-on-one relationship with the Netherlands, either with tighter or looser ties to The Hague. In the very near future, Sint Maarten will become an autonomous territory of the Netherlands.

The political evolution of St. Martin is a response to the great economic and demographic upheavals that the island experienced since the 1960s for the Dutch part, and for the French part it was in the 1980s when economic development based on tourism was set in motion.

\section{THE DEVELOPMENT OF TOURISM}

The economic development of St. Martin is based on the offshore and tourism services it offers. Between the beginning of the 1960s and the beginning of the 1990s, the number of tourists and cruise ship passengers choosing St. Martin as a vacation destination increased fiftyfold. ${ }^{5}$ In 2004, with approximately 1.5 million visitors from cruise ships per year and nearly 500,000 visitors coming to St. Martin by air from the Dutch side - few visitors come by air or sea to the French side because the international airport and deepwater harbor are located in Philipsburg - St. Martin has become the island with the most visitors of all the islands in the Lesser Antilles. ${ }^{6}$ St. Martin has the world's highest tourism penetration index among forty-seven islands with comparable demographic characteristics and a similar level of development. ${ }^{7}$ The French and Dutch sides of the island attract very different types of tourists. Restaurants in Grand Case and luxury boutiques in Marigot appeal to a wealthy clientele, whereas tax refund electronics stores and shops for cheap jewelry in Philipsburg and hotel-casinos draw more middle-class tourists.

Klaus de Albuquerque and Jerome McElroy (1991) have proposed a model for the development of tourism that explains the economic, demographic, and environmental changes of the small islands of the Caribbean whose development is based on tourism. ${ }^{8}$ The model describes three stages:

5. In $1965,23,835$ tourists visited the island; in 1993 there were more than 1,100,000 visitors. See Chardon \& Hartog 1995.

6. Central Bureau of Statistics Netherlands Antilles: http://www.central-bureau-of-statistics.an/traffic/traffic_n7.asp and http://www.central-bureau-of-statistics.an/traffic/traffic_n9.asp.

7. That is, islands with a population of one million inhabitants and an area less than 20,000 km², which have opted for tourism-based development. See McElroy 2004.

8. These authors have simplified and adapted the model to the Caribbean situation, basing it on the "product cycle model" developed in the 1980s by Butler (1980). This model was criticized because characteristics of one stage of development could also be those of 
emergence, expansion, and maturity, the last being characterized by slow or no growth at all (de Albuquerque \& McElroy 1991, 1995). The evolution of tourism on St. Martin is a good example of this process. From an island that was frequented by the jet set, it has become an island of middle-class tourism, one that consists in particular of cruise ships that disembark a stream of visitors who come to spend one day in the tax refund stores in Philipsburg. ${ }^{9}$

The emergence phase corresponds to the 1960s, when subsequent to the U.S. embargo on Cuba, St. Martin became a destination for wealthy Americans (Samson 1989). The first hotels were small and were built on the waterfronts at Philipsburg and Little Bay.

The expansion phase began in the 1970s in Sint Maarten and in the 1980s in Saint Martin. On the Dutch side it was marked by the development of mass tourism with the construction of hotel complexes that had a capacity of 100 to 600 rooms and a casino. The number of rooms doubled between 1980 and $1990 .{ }^{10}$ Investments that made possible the development of tourism on the French side were prompted by tax exemption regulations; the first, called Loi Pons, dates from 1986 and reduced the income taxes of individuals and introduced tax breaks for companies. The number of hotels increased by more than thirty between 1986 and 1992. Marinas were constructed to attract luxury yachts.

In 1990, the Caribbean was the primary tropical tourist destination: eleven million tourists vacationed there, and St. Martin was the most popular destination in the Lesser Antilles with 23.6 percent of all who visited that part of the archipelago going there. In 1990, St. Martin became the fourth most popular destination for cruise ships after Puerto Rico, the Bahamas, and the U.S. Virgin Islands. The number of cruise ship passengers spending a day on the island increased fivefold in ten years. ${ }^{11}$ In twenty years, the number of tourists arriving via Princess Juliana International Airport was multiplied by five: from 100,000 in 1970 to 528,315 in 1991.

The 1990s correspond to the maturity phase. Hurricane Luis (1995) is generally seen as the cause of the decline in tourism because of the infrastructure it destroyed, and because it was followed by other hurricanes (George in 1998 and Lenny in 1999). Effectively, since 1995 the number of people coming to the island had decreased, while vacancies in hotels had increased, though the early warning signs of diminished tourism could already be detected since the early 1990s. Since 2003 the number of visitors and the

other stages and because they represent the development as being linear, which it is not always the case (Thomas, Pigozzi \& Sambrock 2005). See also McElroy 2006.

9. The following remarks are based on my own observations and those of Sanguin 1982, Samson 1989, Chardon \& Hartog 1989, 1995, and de Albuquerque \& McElroy 1991, 1995.

10. From 1,670 in 1980 to 3,500 in 1990 (de Albuquerque \& McElroy 1995:76).

11. 105,000 visitors in 1980 as compared to 515,000 in 1990 . 
occupancy of hotels have risen on the Dutch side, though they have not yet attained pre-Luis figures. On the other hand, the number of cruise ship passengers spending a day on the island is increasing significantly. ${ }^{12}$

\section{The DEMOgRAPHIC COMPOSITION OF ST. MARTIN}

The construction and exploitation of the tourism infrastructure on St. Martin has relied on labor from the poorest Caribbean islands. These laborers were employed in construction and in the very lowest positions in the service industry and they lived in precarious conditions. Management positions, on the other hand, were held by Europeans, mostly from France. From 1970 to 1990 the population increased by a factor of five and went from 14,000 in the 1970 s to more than 60,000 at the end of the 1990 s. $^{13}$

In 1999, the year of the last census of the entire population of Saint Martin, ${ }^{14}$ French of metropolitan origin or from Guadeloupe constituted just over 65 percent of the total population, with those said to be originally from Saint Martin estimated at 15 percent of the total population. ${ }^{15}$ The proportion of people of foreign origin was about 32 percent of the population, with a majority from the Caribbean. The proportion of the population living in Saint Martin that originally came from Haiti was 11 percent, about 5 percent came from Dominica, and 4 percent from the Dominican Republic. ${ }^{16}$

In 2001 the demographic composition of Sint Maarten was appreciably different from that of Saint Martin. The Dutch population originally from the Netherlands, the Federation of the Netherlands Antilles, or born on Sint Maarten was 50.6 percent. It was thus smaller than the French population of Saint Martin, though Sint Maarteners are more numerous than Saint Martinois, accounting for 30.5 percent of the population. The foreign-born population on

12. From 1991 to 2006 the yearly number of visitors has tripled: it has gone from 469,667 to 1,421,645 (personal communication, Edward Dest, St. Maarten Tourism Bureau, 2007). 13. According to the 1999 census, 29,112 on the French side. According to the intermediary census in 2001, 30,594 on the Dutch side. In 2005 the population of the island numbered $73,035,38,000$ on Saint Martin (data estimated by INSEE - Antilles Guyane \& ACSE 2006:9), and 35,035 on Sint Maarten (data estimated by the Central Bureau of Statistics 2005:13).

14. Since January 2004, the census of the resident population in France has been carried out annually and is based on a sample of the population. Before that, it was taken every eight years and concerned the entire population.

15. This is an estimate because the census does not distinguish between Saint Martinois from the French Antilles and metropolitan French, contrary to the census of Sint Maarten, which does make the distinction.

16. I calculated these percentages from the data of INSEE - Antilles Guyane \& ACSE (2006:17). 
Sint Maarten is more significant, constituting nearly 50 percent of its population. More than 30 percent of the total population is Caribbean: 10.1 percent of the population on Sint Maarten is from the Dominican Republic, 9.7 percent from Haiti, 12.4 percent from Jamaica, Dominica, and Guyana.

According to the 1990 census, the percentage of foreigners living on Saint Martin was comparable to that of Sint Maarten, with proportionally more Haitians living on the French side. ${ }^{17}$ Between the census in 1990 and the one in 1999, the number of foreign-born inhabitants decreased by 5,700, with 2,600 of them being Haitians. ${ }^{18}$ The population of foreign-born inhabitants on Saint Martin decreased by 38 percent; whereas it represented 53 percent of the population in 1990, it was no more than 32 percent in 1999. The reduction in the number of foreigners on Saint Martin is directly related to the policy of deportations implemented by the French government. From 1992 to 1997 , this policy led to the deportation of 3,275 foreigners. ${ }^{19}$

From an emigration island, with its population in the 1950s migrating to the United States, the island has become an immigration island, with the original population having become a numerical minority and the Caribbean population being kept in a situation where they do not have immigration papers. ${ }^{20}$ In the Caribbean context, such demographic dynamics and fates of foreigners are not exceptional. The same is happening on other small, dependent territories such as the Turks and Caicos Islands, as well as the Bahamas, which in the 1960s also opted for economic development based on offshore financial services and tourism. The exploitation of labor, largely of Haitian origin, enabled development, and now that the infrastructure of these islands has been completed, these laborers are subject to deportation (St. Jacques 2001; Brown 2004). The border prerogatives of nation-states are revealed in the monitoring of labor-related migrations (Puri 2004).

17. The data available from the 1999 census do not give percentages per nationality but according to the double criteria of nationality and place of birth, that is, immigration status. An "immigrant" is a person born a foreigner in a foreign country but living in France. A "foreigner" is a person living in France who does not have the French nationality. On Saint Martin the percentage of foreigners and migrants being more or less the same, I felt I could compare the percentage of migrants on Saint Martin with the percentage of foreigners on Sint Maarten (INSEE - Antilles-Guyane \& ACSE 2006:5). The appearance of the category of "migrant" in INSEE statistics is in fact recent and is based on the political stakes studied by Spire 1999.

18. INSEE - Antilles-Guyane \& ACSE 2006:8.

19. In the aftermath of Hurricane Luis there were 2,769 expulsions and 506 voluntary departures (personal communication with the air and border police (PAF), August 1998; I was unable to obtain the figures for 1990-1991 and 1998-1999).

20. For an introduction to the complexity of Caribbean migration patterns in regard to the legal/illegal status of migrants, see Martinez 1999. 
Because there was no monitoring of foreigners by the French government before the former were admitted to the island, deportations took the place of the nonexistent border inspections and therefore played the role of external borders. Until August 2007, Saint Martin was an exception as regards the administration of its borders. First of all, the French government had no means of monitoring foreigners entering the island, regardless of whether they were visitors or residents. A large majority of people coming to the island come via Princess Juliana Airport or the harbor at Philipsburg, both on the Dutch side, where the air and border police (Police de l'air et des frontières, PAF) cannot operate. Besides, there is no border checkpoint that stands as a physical reminder of the border and shows the links of the two sides with their European metropoles or regulates the flow of people and goods between the two parts of the island. Travelers and residents move from the Dutch to the French side without being asked to show identification, in accordance with the Treaty of Concordia, which, in 1948, ratified the joint use of the island by France and the Netherlands and set the conditions for the circulation of people and goods. Only a monument erected in 1948 to the glory of three centuries of peaceful coexistence stands as a physical reminder of the border. The borders of the French territory are thus defined by Dutch legislation and are monitored by Dutch police.

Deportations occur at a proportionally greater frequency in the overseas territories than on metropolitan French soil. The French laws regulating the conditions for the entry and stay of foreigners in France contain specific articles for these territories which facilitate monitoring and deportations.

\section{IMMIGRATION LAWS AND THE REINFORCEMENT OF BORDERS}

The overseas regions that, together with the French metropole, make up the Republic of France, include several institutional categories of territories. Apart from uninhabited territories and New Caledonia, which has a specific status, the first category of territories includes the former colonies of Guadeloupe, Martinique, French Guiana, and Réunion, which have acquired, with the assimilation law of March 19, 1946, the status of French overseas department (Département d'outre-mer, DOM). Since 2004 these DOMs have been designated as departments and overseas regions (Départements et régions d'outre-mer, DROMs), confirming that each of these entities is a monodepartmental region. ${ }^{21}$ The second category comprises the overseas

21. In continental France, departments and regions are two distinct administrative entities, the region encompassing several departments. Each administrative entity is represented by an assembly - the general council for a department and the regional council for a region. The DROM is both a department and a region and it is represented equally by two assemblies. 
collectivities of St. Pierre and Miquelon, Mayotte, Wallis and Futuna, French Polynesia, St. Barthelemy, and Saint Martin.

The French Republic is a plurilegislative state (Rolland \& Lampué 1949). Legislation concerning the DROM comes under the principle of assimilation and is identical to that of the departments and regions of France on the continent, unless, as the constitution of 1958 - the founding text of the Fifth Republic, which is still in force - indicates, their situation requires adaptations. These measures may not concern certain spheres such as nationality, civil rights, the administration of justice, and criminal law. The laws regarding the COMs, with the exception of those applicable to St. Pierre and Miquelon, are based on the principle of exceptionalism: the laws are not applied automatically but only when their application is signaled by specific language to that effect.

The presence of foreigners in overseas territories is considered by the legislature to be a specific situation requiring adaptive measures. These measures may concern a department or even a district within a department, in the case of Saint Martin, or specific regions within a department, in the case of French Guiana and now Guadeloupe, showing the territorial applicability of the law. These measures accompany more restrictive policies than those defined for the territory of the French metropole. In the case of the COM, legislation is defined by an ordinance specific to each collectivity.

An analysis of the legislation concerning the conditions for the entry and stay of foreigners allows for a concrete understanding of the implementation of immigration policies by the French government. It shows that a border is not so much a physical demarcation as a political project. "The boundary is not a spatial fact with sociological consequences, but a sociological fact that forms itself spatially," to quote Georg Simmel's 1993 groundbreaking analysis (Frisby \& Featherstone 1997:143). ${ }^{22}$ Borders must be analyzed not as a limit, but in the context of the internal political project of the country that constructs them (Febvre 1962, 1949).

Until 2005, immigration laws in France were governed by the ordinance of November 2, 1945 on the entry and stay of foreigners in France. This ordinance was regularly modified in accordance with immigration policies defined by the government, leading on March 1, 2005 to the Code de l'entrée et du séjour des étrangers et du droit d'asile (Ceseda; Code concerning the entry and stay of foreigners and the right to asylum), which has already been modified by two laws. ${ }^{23}$ Following the 1973 oil crisis the French government

22. Georg Simmel's analysis of boundaries is part of an essay published in 1903, "Soziologie des Raumes," translated for the first time in English in 1997 with the title "Sociology of Space" in Frisby \& Featherstone (1997).

23. The law of July 24, 2006 regarding immigration and integration and the law of November 20, 2007 regarding control of immigration, integration, and asylum. 
put an end to labor immigration. The modifications to the 1945 Ordinance, with the exception of the modifications made during the first office of the French socialist president, François Mitterand (1981-1988), and two laws passed modifying the Ceseda are inclined toward restrictions to the entry and stay of foreigners on French territory.

It was not until 1980 with the act of January 10 called Loi Bonnet that the scope of the applicability of the 1945 Ordinance was extended to include the overseas departments. Until then, immigration laws were governed by two decrees dating from colonial times, one from July 29, 1935 for Guadeloupe, Martinique, and Réunion, the other from November 4, 1936 for French Guiana. Nevertheless, certain aspects of these decrees regarding the circulation of foreigners between the overseas departments and the French metropole applied until 1987 (Rodier 1999).

Since 1980, immigration laws always contain specific articles for the overseas territories. These adaptations are characterized by more restrictive conditions for the entry, transit, and stay of foreigners, extended identity checks, and the easier and more rapid implementation of deportations. ${ }^{24}$ Legislatively, notably for Saint Martin, these adjustments took several forms:

- The application of a law favorable to the conditions of stay of foreigners on French continental territory may be deferred for the overseas departments. Thus Loi Deferre, an act passed in 1981 which repeals the unfavorable provisions of Loi Bonnet, was postponed for five years for the DOMs. ${ }^{25}$

- The application of particular articles of a law may be postponed. Thus the law of August 2, 1989 created the Commission du titre de séjour (an advisory body which conveys its recommendation to the prefecture as to the right of a foreigner to apply for the renewal of his or her resident permit) which the prefect must consult if he/she considers refusing the granting of or the renewal of a residency visa, the commission being only an advisory body. The law of January 10, 1990 created the possibility of filing a suspensive appeal with a judge against a deportation order so that a foreigner may be allowed to stay in France until the decision by a tribunal. These two laws postponed for five years the application of these provisions for the DOMs and St. Pierre and Miquelon. The law of August 24, 1993 once more prolonged this exception for another five years, after which Loi Chevènement of 1998 extended it once again for five years for Saint Martin and French Guiana.

24. For a chronological review of legislation concerning foreigners, see Alaux 1997; GISTI, Cercle Frantz Fanon, Association des juristes pour la reconnaissance des droits fondamentaux des immigrés 1989; GISTI 2007.

25. In fact it never took effect because in 1986 the return of the political Right to power in the first coalition and the passing of the Loi Pasqua in the same year also meant a return to the positive aspects of the Loi Deferre. 
- The permanence of restrictive provisions that were supposed to be temporary. The internal security law of March 18, 2003 makes permanent the postponement of five years for the creation of a Commission du titre de séjour and the possibility of suspensive appeal for Saint Martin and French Guiana.

- The extension of articles enacted for one commune or one DROM to other communes or DROMs. The July 24, 2006 law called Loi Sarkozy extended for a period of five years to the whole of Guadeloupe the nonsuspensive character of appeals against deportation orders; until then this provision had only existed in the department for the commune of Saint Martin. The same law gives Guadeloupe and Mayotte the right to carry out identity checks without written permission from the district attorney; until then that possibility had only existed for French Guiana (since 1997). ${ }^{26}$

The right to asylum, which is the same for the metropolitan and overseas territories is, in fact, applied differently, and overseas requests for refugee status have little chance of succeeding (Castagnos-Sen 2006).

In the same way as for immigration laws, circulation between the DROM and the metropole betrays a dual perception of French territory:

- The enforcement decree of the Schengen Convention, signed in 1995, which allows a foreigner with a short-stay visa (called a Schengen visa) entering one of the signatory countries, or one of those associated with the convention, to travel freely between these states does not apply to the French overseas territories even though it does apply to the overseas territories of Spain - the Canary Islands - and Portugal - the Azore Islands and Madeira.

- A Schengen visa, which is valid for entry to the French metropole, is not valid for the DROM and vice versa.

- Even if no visa is required to enter the French metropole, a visa may nevertheless be required for the DROMs, depending on the nationality of the foreigner (Duflo 2007).

- Different visas are necessary to travel from one DROM to the other, except those in the Americas (Rodier 1999).

\section{DEPORTATIONS IN THE GUISE OF BORDER CONTROL}

Between 2002 and 2007, when the present president of the French Republic, Nicolas Sarkozy, was the Minister of the Interior (2002-2004 and 2005-2007) five laws pertaining to immigration or asylum and five other laws concern-

26. In France, the police may only check one's identity in the event of a flagrant delict or with a written order from the public prosecutor for a specific zone in the territory where offences are likely to occur. 
ing criminal infractions, the war on terrorism, and security were passed. In 2003 the implementation of a policy aiming to increase the number of deportations of foreigners without documents led to, in 2006, quotas being assigned to each prefecture, and the civil servants at these prefectures are penalized if they do not meet their set targets..$^{27}$ The creation of a Ministry of Immigration, Integration, National Identity, and Co-development (Ministère de l'immigration, de l'identité nationale et du co-développement) by presidential decree on May 18, 2007 upholds the idea that migrants threaten the identity of the French nation - insofar as the concept of a national identity is pertinent - and that they must be deported.

The use of the word rafle (raid) for the massive arrests of foreigners is subject to debates in France because historically it was used as a term for the arrests of Jews during World War II and the Algerian population during the Algerian War of Independence. The Dictionnaire historique de la langue française (The historic dictionary of the French language) unambiguously defines rafle as a "police method" consisting of "arresting people in great numbers" (Rey 2000). An examination of the attitude and methods of the French police in the past and today shows similarities that justify using the term. There are at least four similarities:

- a certain number of individuals living on French soil are considered undesirable;

- techniques used to detain people designated as suspects are identical: sending misleading invitations to prefectures to "trap" the undocumented foreigner once there, the school arrests of children for so-called humanitarian reasons, that is, so as not to separate deported parents and children - though detaining parents whose children are born and go to school in France could be considered humanitarian - home arrests, mass arrests by neighborhood racial profiling;

- confinement in detention centers before deportation;

- group deportations, these days in charter flights. ${ }^{28}$

27. Because they had not met the quotas assigned to their departments, nineteen prefects were summoned on October 14, 2007 by the Minister of the Interior (M. C. T. \& A. N., "Brice Hortefeux convoque les préfets qui n'expulsent pas assez," Le Figaro, October 14, 2007). The French president dismissed the director of the police générale of the prefecture of Paris (DPGPP) by decree on January 16, 2008 for not having met the deportation quota: he had been responsible for only 2,800 instead of 3,680 deportations (Giovannoni 2007).

28. For this analysis I draw upon Terray 2006, and blogs by Jean-Pierre Dubois, "Techniquement, rafle est le mot juste," Contrejournal, 27 September 2007, http://contrejournal. blogs.liberation.fr/mon_weblog/2007/09/jean-pierre-dub.html, and Laurent Giovannoni, "Les rafles ont commencé quand la police avait du mal à atteindre ses objectifs," Contrejournal, 28 September 2007, http://contrejournal.blogs.liberation.fr/mon_weblog/2007/ 09/giovannoni.html. 
The increase in the number of deportations and the manner in which arrests are conducted have led the secretary general of Cimade, an association which plays a major role in France in supporting and defending foreigners, in particular of people requesting asylum, to speak of "the industrialization of deportations." 29

Though the raids in metropolitan France in their current form reappeared in 2003, when through the circular of October 22, the Ministry of the Interior requested that the number of deportations be doubled, they had already been taking place in the overseas territories at the beginning of the 1990s, especially in French Guiana and on Saint Martin, where adaptations to the 1945 Ordinance facilitated deportations. Everyone living on Saint Martin in the 1990s can recall the early-morning police raids: the red vans of the PAF driving towards the Haitian neighborhoods, men warning, by telephone or by cries, of the arrival of the police, the encircling of the neighborhoods, warrantless work and home arrests, and the airplanes on Tuesdays and Fridays at the Grand Case airport that flew off the deportees without the legal deportation measures having been observed. Hurricane Luis, which in September of 1995 left the island in ruins, presented the French state, the municipality of Saint Martin, and the government of Sint Maarten with the opportunity of razing the shanty towns of the island, the collection of "cardboard palaces" as two journalists called them, and increasing the number of deportations..$^{30}$ A delegation of lawyers, members of a Martiniquan association in support of foreigners' rights (Association Solidarité Karayib, ASSOKA), as well as a larger delegation consisting of several French associations for the protection of the rights of foreigners and the unions of judges and lawyers of France (Syndicat de la magistrature, Syndicat des avocats de France) concluded that the destruction of these homes was illegal. Several French tribunals recognized the responsibilities of the municipality and the French government, but appeals slowed down the procedures leading to compensation (Manville 1999). The arrests took place in the morning at the time that workers were heading to their jobs, and on days when Maternal and Child Health Office (Protection maternelle et infantile) visits were held at the hospital or public clinics. This led to diminished activity at the hospital in Marigot and there was a notable decrease in the number of deliveries following Hurricane Luis (Bardinet, de Caunes \& Hamlet 1995). From 1993 to 1997 there were about 460 to 600 deportations

29. Karl Laske, "Interview de Laurent Giovannoni 'On est confronté à une industrialisation de l'éloignement," Contrejournal, December 28, 2007, http://contrejournal.blogs. liberation.fr/mon_weblog/2007/12/on-est-confront.html.

30. Mario Kleinmoedig \& Henky Looman, "Paleizen als van 'karton," Beurs Magazine, no. 12, 1995, pp. 14-17. Where Saint Martin is concerned, as of December 31, 1995, the number of official voluntary returns since September 6, 1995 was 506, the number of deportations between September 6 and December 31 was 190 (ASSOKA et al. 1996). 
per year. They seem to have decreased thereafter: from 2001-2006 there were 1,931 deportations, an average of 257 per year. ${ }^{31}$

The year 2006, which is the year deportation quotas were introduced, marks a turning point in the increase of deportations. They reached a figure of 413, surpassing the objective of 280 set by the Ministry of the Interior. The number for the first half of 2007 was 263, whereas the goal set by the Ministry of the Interior was 300 for the year. Identity checks are carried out as part of the raids, or on a more individual basis, such as in the operating room of the hospital of Saint Martin.

The refusal of employers to register their employees, the near total absence of social assistance for undocumented or documented foreigners from the commune of Saint Martin and the regional council of Guadeloupe, and the infrequency with which residence permits are granted together shape the precariousness of the living conditions of the foreign population, so that these populations are more susceptible to economic exploitation. The foreign population lives in "legal and structural marginalization," to quote Paul Brodwin's characterization of the Haitian situation in Guadeloupe, which makes their economic exploitation easier and facilitates their deportation when they are deemed to have become too numerous (Brodwin 2003). Undocumented foreigners are people who work but who are not registered. In many cases employees, if they wish to be registered, pay their employers social security taxes. The number of jobs rose from 2,800 in 1982 to 12,000 in 1990, but there were hardly 400 employees registered between 1985 and 1991 for the 2,685 companies operating on the island (Marie 1991). After Hurricane Luis, to protest against the growing number of deportations which were going to deprive them of cheap labor, some entrepreneurs went as far as slashing police car tires to limit the number of round-ups (Alaux \& Tillie 1996). According to the local intelligence services, between 5,000 and 10,000 persons are presently undocumented on Saint Martin, which amounts to between 40 and 80 percent of the 13,000 "immigrants" living on the territory (Comité interministériel de contrôle de l'immigration 2007:170-1; INSEE - Antilles Guyane \& ACSE 2006:9).

\section{“Inbetweenity," The Political Borders of Social Welfare, AND THE "REGIME OF MOBILITY"}

The concept of "inbetweenity" proposed by Dennis Brown (2004) to characterize the position of Haitian migrants on the Turks and Caicos Islands also applies to the Caribbean migrants on Saint Martin, particularly

31. Comité interministériel de contrôle de l'immigration $(2006,2007)$ for the period 2001-2005 and year 2006 respectively. Personal communication with the PAF for the first half of 2007. 
Haitians. As a result of their undocumented sojourn, migrants occupy the social and spatial fringes of their host country - the bush on the Turks and Caicos Islands, certain neighborhoods on the periphery of Saint Martin where they hide away for fear of being deported. In a context of discrimination and human rights violations, on Saint Martin, just as on the Turks and Caicos Islands, migrants access work with difficulty, and health care and social services limitedly. In fact, the borders are deterritorialized; they are institutional (Spener \& Staudt 1998).

For John Crowley (2005) the "institutional border" consists of mechanisms which turn access to social security into a site of immigration control away from the physical border enclosing a territory. On Saint Martin, this institutional border has always existed because of the difficulty, if not impossibility, for foreigners, even those with documents, to get access to the welfare benefits that French law guarantees. In a sense this institutional border became territorial in 1999 with the introduction of CMU (Couverture médicale universelle, free basic medical care for everyone) which requires foreigners to show proof of having been on French soil for three months in order to receive care. This border has been strengthened in that social assistance and the prefecture demand additional proof of residency in order to provide social care or grant residency permits.

Take, for example, the question of the one-year resident permits for care (visa de séjour pour raison médicale) which intersects that of visa delivery and access to social assistance. Obtaining such a one-year, renewable permit, extended to foreigners who suffer from an extremely serious illness which cannot be treated in the country of origin, is a real obstacle course, replete with persecutory measures. How well the file is put together depends upon the abilities of the social workers at the hospital who have increasingly been led to educate themselves about the law in order to be able to deal with the difficulties and arbitrariness of the administration.

The notifications of the medical inspector of Guadeloupe have always been in favor of granting these permits, which the prefecture has never denied until now. Today nearly 350 foreigners benefit from this right to a stay for medical reasons. Nevertheless, the person requesting permission rarely receives an actual document giving permission, but only three-month extension slips. The actual permits are printed in France, and employees of the prefecture recently protested that there was no request form to get them, even though the form is available on the internet. And in the case of permits delivered a few days before their expiry date, employees of the prefecture either throw them away or staple them to the receipt of the renewal request if the receipt is ready at that moment. The permits are only delivered or renewed with great difficulty under the pretext that the person requesting such a permit has committed various offences. Such is the case of Mr. R, who had been suffering from a chronic 
illness for ten years and in August 2005 was refused a seventh permit, with the claim that Martinique had issued a deportation order for him in $1980 .{ }^{32}$

Mr. R asserts that he has never been to Martinique. Since many surnames in the Caribbean are homonymous, there is a strong chance that the deportation order on Martinique was issued for someone else. The subprefecture of Saint Martin, however, demanded that Mr. R supply them with proof that the order has been repealed if he wishes to remain on Saint Martin. In November 2006 the prefecture of Martinique informed the subprefecture of Saint Martin that it cannot repeal the deportation order because the file of $\mathrm{Mr}$. $\mathrm{R}$ or the person with the same name has been lost. The prefecture specified that if Mr. $\mathrm{R}$ does not pose a threat to the public order there is no reason to deny him a medical permit. It was necessary for a Paris-based medical NGO to intervene and appeal to the Prefect of Saint Martin for a temporary authorization for Mr. R, which was granted in July 2007, allowing him to stay for three months. For more than two years, Mr. R did not have residency papers and had lost his medical coverage - as an undocumented foreigner he no longer had access to social assistance - and the various forms of social assistance that he had received until 2005. Moreover, he was in a very vulnerable position if he were to be arrested and issued a deportation order.

In a more banal and practically systematic way, the difficulties with this type of visa begin when the file is put together. Few foreigners are able to furnish the necessary proof of residency, that is, a rent receipt and a water bill bearing their name, or proof of housing with a photocopy of the ID of the renter - no landlord likes to declare that he is lodging an undocumented migrant, if only to avoid being convicted for helping undocumented migrants. As for the required identification papers, a passport, and a birth certificate, the spelling of the names is often different on all documents, leading to suspicion about the identity of the plaintiff. When all documents have finally been assembled, the vigilance, support, and expertise of the medical team at the hospital are needed to trace the files, prepare the renewal requests for the permits two months before the expiry date, keep a copy of the file, and photocopy the permit requests and extension slips, which the prefecture often claims to lose.

The visas for medical reasons belong to the "regime of mobility" that Horng-Luen Wang (2004) conceptualized to designate state control over the movement of persons from the moment a passport or visa has been issued. This "regime of mobility" which defines the political border is based on territorial residency and is more restricted now that Saint Martin is a collectivity.

32. The name and place of residence of this person have been changed to protect his identity. 
THE CREATION OF NEW BORDERS

A speech by the mayor of the commune before the senatorial commission on the island in January 2006 set the tune for upcoming policies concerning foreigners. After having described the way in which "the presence of the population of immigrants overburdens the collectivity in collective needs and resources" he specified "[that] the territory of Saint Martin must be made socially less attractive for its Caribbean neighbors. Revising family reunification is a priority. The same goes for the criteria for settling in the territory, which must become more restrictive. Without this the collectivity will not be able to function and is destined for failure." 33

The territorial council governing the collectivity of Saint Martin elected in July 2007 is currently preparing for the transfer of administrative competencies from the department/region of Guadeloupe and from the French government in the domains of taxation, regional planning, economic development, and social affairs. Activities of the French government proper, such as foreign affairs, security, and immigration laws will remain under the control of the state. The change in status for Saint Martin will see even more restrictive migration policies being put in place. First, just as in the other COMs, an ordinance whose implementation is foreseen in 2008 will regulate the conditions of entry and stay of foreigners and will make deportations easier. Next the enforcement decree of a cooperative accord between France and the Netherlands on the shared surveillance of the island's borders published in 2007 has allowed the PAF to begin the inspection of foreigners arriving on the island.

THE CREATION OF AN INTERNAL BORDER: THE REINFORCEMENT OF THE INSTITUTIONAL BORDER AND ORDINANCE

Even though it is difficult to say precisely what a future ordinance for Saint Martin will contain, it is possible that it will be inspired by that of Mayotte, a COM in the Indian Ocean that has the most deportations of all French overseas territories. The number was at 13,258 in 2006, or 20 percent of the foreign population. ${ }^{34}$ The employees of the prefecture of Saint Martin draw a parallel between the migratory situation on Saint Martin and Mayotte. The poorest people in the Caribbean or on the Comoro Islands are said to be

33. For the full text of the speech, see http://statut.sxml.com/index.php?option=com_con tent\&task=view\&id=202\&Itemid $=35$.

34 . At the time of the census in 2002 , there were 160,265 people. In 2006 , there were 9,633 documented foreigners as opposed to an estimated 50,000 undocumented foreigners (Comité interministériel de contrôle de l'immigration 2007:171). 
attracted to the island and they are said to migrate to French territories not because they find work there, but because their families benefit from social welfare, their children have access to the French educational system, and the women can deliver their babies in a French hospital. In the case of Saint Martin, one forgets that undocumented foreigners were reported to the PAF in hospitals and that numerous foreigners, in particular Haitians, had their passports confiscated at the front desk until they were able to pay the costs of their care, which could amount to several thousands of euros..$^{35}$

Without an internal border, people are able to circulate freely, that is, without an identity check, between the French and the Dutch sides of the island. The French and Saint Martin authorities ceaselessly emphasize that not only undocumented foreigners living on the French side use the social, sanitary, and educational infrastructure, but also foreigners living on the Dutch side, who are not able to access care and the educational system without costs. The issuing of permits and the granting of social assistance will require a greater number of documents proving residence by the French side.

The ordinance will reincorporate the restrictive articles of the law of July 24, 2006, called Loi Sarkozy 2, for Guadeloupe, notably the identity checks without written authorization from the district attorney within a one-kilometer zone along the coastline. Given the shape and layout of Saint Martin, the inspections along the coastlines on the east and west will in fact function as internal border inspections while the border has no physical presence in the form of border control checkpoints.

\section{The MATERialization of AN EXTERnAl Border: SHARED BORDER INSPECTIONS BETWEEN THE FRENCH AND THE DUTCH}

An important change, tied to the signing on August 21, 2007 of an enforcement decree of a cooperative treaty between France and the Netherlands on the shared inspection of the borders and retroactive since August 1, 2007, is going to take effect. ${ }^{36}$

A pilot committee of ten people, amongst them two lawyers, is being assembled for the implementation of this treaty. PAF agents will be in charge of border surveillance for Saint Martin, while agents of the foreign police are charged with the responsibility on Sint Maarten. According to Article 13 of this treaty, agents will carry out the inspection of foreign nationals, except those from European countries, coming from countries to be drawn up in a

35. It was not until September 2007 that one of the key figures involved in this form of embezzlement was arrested and incarcerated in Guadeloupe.

36. This accord, the groundwork of which began in 1979, was signed by France and the Netherlands on May 17, 1994 and then ratified by the French National Assembly on July 25, 1995 and the parliament of the tripartite Kingdom of the Netherlands in October 2006. 
list by the pilot committee. The pilot committee will instate a working group in charge of identifying flights that are "sensitive"; the list will be kept upto-date for joint controls. An emergency procedure will be put in place for flights that are not on the list but which turn out to need inspection.

Entry will be granted in accordance with the conditions defined by Article 4 , that is, essentially the possession of "a visa or a disembarkation authorization valid for both sides of the territory allowing the crossing of the border." This treaty will lead to the harmonization of the list of countries from which the citizens must have a visa to enter the island. If PAF agents ask for the removal of a person, the police of Sint Maarten will make the decision to remove that person.

"The border is an active verb" wrote Henk van Houtum (Van Houtum, Kramsch \& Zierhofer 2005:3). In the case of the French overseas departments, the borders are active verbs of inspection and rejection of foreigners. Upon a proposal by the present Minister of European and Foreign Affairs, Bernard Kouchner, the senatorial committee of foreign affairs adopted, on December 11, 2007, a bill on transborder cooperation between France and Suriname to monitor the movement of people from one side of the Maroni River, while the populations living along the river have always occupied both sides at the same time - their settlements could be on the French side while their gardens were on the Surinamese side. ${ }^{37}$

The treaty is supposed to be the cornerstone of future policies on border inspections on Saint Martin, to such a point that for some employees of the prefecture "if the inspection of the entry of adults is going to be sorted out at Juliana Airport, we must focus on the code of nationality and the children." On Mayotte, Ceseda already authorizes the registrar to contest the acknowledgement of paternity, and a bill seeking to revise the nationality code was up for proposal in Parliament before being rejected by the Council of State (Uni-e-s contre une immigration jetable 2007).

In this context of border closings, the border is not simply a physical line marking the separation between two territories, it is made up of "ports of entry" which are, according to the analysis by Heyman (2004), the "nodes" of a world that is shutting itself off to the movements of populations.

\section{CONCLUSION}

The status change suggests four issues for a future research agenda. First, the institutional evolution of St. Martin toward a status of association with, rather than total independence from, the European metropoles follows the evolu-

37. For a summary of Bernard Kouchner's hearing before the senatorial commission on foreign affairs, see http://www.senat.fr/bulletin/20071210/etr.html\#toc. 
tion of numerous small microinsular states which do not seek total political independence but which explore the various kinds of associations with their metropoles in order to retain the political and economic advantages tied to this dependence..$^{38}$ Even more paradoxical, however, is that the transformation of Saint Martin into a COM reinforces the presence of the French government on the territory. How, therefore, do we characterize the postcolonial situation of the French overseas territories? Second, the creation of the COM entails the creation of a territory at an almost primary level: the delimitation of a new political entity by means of borders. As such, the anthropology of borders is also an anthropology of nationalisms that need to be closely explored (Wilson \& Hastings 1998). Third, the place of Saint Martin in migratory policies illuminates the central role of the peripheral territories in defining France and Europe. Since the 1990s the island has been closing itself off to migrants, and the status of COM creates and strengthens new borders. St. Martin, called the "Friendly Island," is often described as a laboratory for cultural encounters (Guadeloupe 2006), but in reality the island is an experimental laboratory of repressive policies regarding foreigners (Migrants Outre-Mer 2007). The cooperative accord on the shared monitoring of the island's borders, the possibility of border inspections at the airport, the reinforcement of the institutional border for access to social assistance, the greater ease with which identity checks can be done and with which deportation can take place are all means which France and the European Union have also put in place to monitor the presence of foreigners on European soil (Tsoukala 2005). The island has become an outpost for the most restrictive immigration policies of France and Europe. The borders of Saint Martin, like those of other DROMs, are the borders of overseas Europe. "The overseas fortress" is thereby one of the first walls of a Europe which is closing itself off to migratory movements (Uni-e-s contre une immigration jetable 2007). Actually, the study of border crossing in the context of globalization is the study of the permeability of borders, especially as concerns the circulation of capital, but it is also the study of the "bounding of bordering process" (Newman 2005), of "rebordering" (Spener $\&$ Staudt 1998), and of the closing of borders to the poorest populations and political refugees (Guild 2005). In the case of Saint Martin, and also of French Guiana and Mayotte, these borders are closing to the historical movements of populations in the region. For Mayotte and French Guiana, the migrant populations considered to be "illegal" are populations who, not long ago, were French, such as that of the Comoros before the 1975 independence from France, or populations that never defined themselves as French or non-French

38. For a typology of the kinds of governance in the Small Antilles and the advantages of dependence, see Hintjens 1994, 1997, McElroy \& Pearce 2006a, McElroy \& Sanborn 2005, McElroy 2006. For an analysis of separatist and autonomous tendencies, see Taglioni 2005. For the Dutch Antilles see Oostindie 2006, Oostindie \& Klinkers 2003. For Sint Maarten see Altink 2003. 
but as being transborder communities, such as in French Guiana. These immigration policies are being developed at a time when France is also conducting cultural, linguistic, and religious battles in these territories. The implementation of these immigration policies on the fringes of the former colonial empire reflects the reinforcement of a republican ideal which rejects the demographic and cultural diversity of the French population.

\section{REFERENCES}

AlaUX, JeAN-PIERRE, 1997. Des DOM en minidroit. Plein Droit (36-37):59-61.

— \& PATRICK TILlie, 1996. Les charmes discrets de l'Etat minimal. Plein Droit 31:2225.

ALTINCK, HENRICE, 2003. Remove or Retain?: The Border Question in St. Martin in the 1990s. Journal of Eastern Caribbean Studies 28(4):26-55.

ASSOKA, CCFD, GISTI, MEDEL, CIMADE, SAF, and SM, 1996. Des étrangers sans droits dans une France bananière: En Guyane et à Saint-Martin. Paris: ASSOKA.

Bardinet, Franck, François de CAunes \& JeAn-LuC Hamlet, 1995. Ile de SaintMartin: On n'expulsera pas l'épidémie par charter. Le journal du sida (79):37-38.

BRODWIN, PAUL, 2003. Marginality and Subjectivity in the Haitian Diaspora. Anthropological Quarterly 76(3):383-410.

BRown, DenNIS A.V., 2004. Inbetweenity: Marginalisation, Migration and Poverty Among Haitians in the Turks and Caicos Islands. In Sandra Courtman (ed.), Beyond the Blood, the Beach and the Banana: New Perspectives in Caribbean Studies. Kingston: Ian Randle, pp. 135-52.

BUTLER, RICHARD W., 1980. The Concept of a Tourist Area Cycle of Evolution: Implications for Management of Resources. Canadian Geographer 24(1):5-12.

CAStagnos-SEN, ANNE, 2006. Les conditions d'exercice du droit d'asile en France. Paris: La documentation française.

Central Bureau of Statistics (CBS), 2002. Fourth Population and Housing Census Netherlands Antilles 2001 vol 1 and 2. Willemstad, Curaçao: Central Bureau of Statistics.

—, 2005. Statistical Yearbook of the Netherlands Antilles. Willemstad, Curaçao: Central Bureau of Statistics.

CHARDON, JEAN-PIERRE \& THIERRY HARTOG, 1989. Essai de typologie du tourisme antillais. In Centre d'études de géographie tropicale du CNRS (ed.), Iles et tourisme en milieux tropical et subtropical. Talence, France: Agence de coopération culturelle et technique, pp. 21-33.

—, 1995. Saint-Martin ou l'implacable logique touristique. Les cahiers d'outre-mer 48: 21-33. 
COMITÉ INTERMINISTÉRIEL DE CONTRÔLE DE L'IMMIGRATION, 2006. Les orientations de la politique de l'immigration: Troisième rapport établi en application de l'article L. 111-10 du code de l'entrée et du séjour des étrangers et du droit d'asile. Paris: La documentation française.

—, 2007. Les orientations de la politique de l'immigration: Quatrième rapport établi en application de l'article L.111-10 du code de l'entrée et du séjour des étrangers et du droit d'asile. Paris: La documentation française.

Crowley, John, 2005. Where Does the State Actually Start? The Contemporary Governance of Work and Migration. In Didier Bigo \& Elspeth Guild (eds.), Controlling Frontiers: Free Movement into and within Europe. Hants, U.K.: Ashgate, pp. 140-60.

CunNingham, HILARY, 2004. Nations Rebound?: Crossing Borders in a Gated Globe. Identities: Global Studies in Culture and Power 11(3):329-50.

— \& JOSIAH MCC. HEYMAN, 2004. Introduction: Mobilities and Enclosures at Borders. Identities: Global Studies in Culture and Power 11(3):289-302.

De Albuquerque, Klaus \& Jerome L. McElroy, 1991. Tourism Styles and Policy Responses in the Open Economy-Closed Environment Context. In Norman P. Girvan \& David Simmons (eds.), Caribbean Ecology and Economics. St. Michael, Barbados: Caribbean Conservation Association, pp. 143-64.

—, 1995. Tourism Development in Small Islands: St Maarten/St Martin and Bermuda. In David Barker \& Duncan F.M. McGregor (eds.), Environment and Development in the Caribbean: Geographical Perspectives. Mona, Jamaica: The University of the West Indies Press, pp. 70-89.

DUFLO, MARIE, 2007. Où est "la France"? Plein Droit (74):3-6.

FEBVRE, LUCIEN, 1949. La terre et l'évolution humaine: Introduction géographique à l'histoire. Paris: Albin Michel.

—, 1962. Pour une histoire à part entière. Paris: Editions de l'Ecole pratique des hautes études.

Frisby, DAVID \& MiKe FEATHERSTONE (eds.), 1997. Simmel on Culture - Selected Writings. London: Sage.

GISTI, Cercle Frantz Fanon, Association des juristes pour la reconnaissance des droits fondamentaux des immigrés, 1989. Immigration dans les DOM: un statut colonial. Plein Droit 8:28-33.

—, 2007. Les spécificités du droit des étrangers outre-mer: Coll. Les cahiers juridiques $d u$ GISTI. Paris: GISTI.

GuAdeloupe, FRANCIO EFRAÏN, 2006. Chanting down the New Jerusalem: The Politics of Belonging on Saint Martin \& Sint Maarten. Amsterdam: Rozenberg.

GuILD, ELSPETH, 2005. The Legal Framework: Who is Entitled to Move? In Didier Bigo \& Elspeth Guild (eds.), Controlling Frontiers: Free Movement into and within Europe. Hants, U.K.: Ashgate, pp. 14-48. 
Heyman, JosiaH MCC., 2004. Ports of Entry as Nodes in the World System. Identities: Global Studies in Culture and Power 11(3):303-27.

HINTJENS, HELEN M., 1994. Évolution politique et constitutionnelle des Antilles françaises depuis 1946. In Richard Burton \& Fred Réno (eds.), Les Antilles-Guyane au rendez-vous de l'Europe: Le grand tournant. Paris: Economica, pp. 19-35.

-, 1997. Governance Options in Europe's Caribbean Dependencies. The Round Table The Commonwealth Journal of International Affairs 86(344):535-47.

HOUTUM, HENK VAN, OLIVIER KRAMSCH \& WOLFGANG ZIERHOFER, 2005. B/ordering Space. Hants, U.K.: Ashgate.

Hyest, JeAn-JACQues, Christian CoINTAT \& SimON Sutour, 2005. Rapport d'information fait au nom de la commission des Lois à la suite d'une mission effectuée en Guadeloupe, à Saint-Barthélemy, et à Saint-Martin du 9 au 14 décembre 2004 par MM. Annexe au procès-verbal de la séance du 10 mai 2005. Paris: Sénat.

InSTITUT NATIONAL DE LA STATISTIQUE ET DES ÉTUDES ÉCONOMIQUES (INSEE) Antilles-Guyane \& Agence nationale pour la Cohésion Sociale et l'Égalité des chances (ACSE), 2006. Atlas des populations immigrées de Guadeloupe. Pointe-à-Pitre: INSEE Antilles-Guyane.

MANVILle, Alain, 1999. Epuration violente à Saint-Martin. Plein Droit 43:11-19.

MARIE, ClaUde-VAlentin, 1991. Travail illégal et immigration irrégulière dans les départements d'outre-mer. Le cas: Saint-Martin. Paris: Ministère des départements et territoires d'outre-mer.

MARTINEZ, SAMUEL, 1999. Migration from the Caribbean: Economic and Political Factors versus Legal and Illegal Status. In David W. Haines \& Karen E. Rosenblum (eds.), Illegal Immigration in America: A Reference Handbook. Westport CT: Greenwood Press, pp. 27392.

McElroy, Jerome L., 2004. Global Perspectives of Caribbean Tourism. In David Timothy Duval (ed.), Tourism in the Caribbean: Trends, Development, Projects. London: Routledge, pp. 39-56.

—, 2006. Small Island Tourist Economies across the Life Cycle. Asia Pacific Viewpoint 47(1):61-77.

—, \& KARA B. PeARCE, 2006. The Advantages of Political Affiliation: Dependent and Independent Small-Island Profiles. The Round Table - The Commonwealth Journal of International Affairs 95(386):529-39.

—, \& K. SANBORN, 2005. The Propensity for Dependence in Small Caribbean and Pacific Islands. Bank of Valletta Review 31:1-18.

MigRANTS OUTRE-MER, 2007. L'outre-mer-Laboratoire de la "lutte contre l'immigration clandestine." Paris: Migrants Outre-Mer. 
NEWMAN, DAVID, 2005. From the International to the Local in the Study and Representation of Boundaries: Theoretical and Methodological Comments. In Heather N. Nicol \& Ian Townsend-Gault (eds.), Holding the Line: Borders in a Global World. Vancouver: University of British Colombia Press, pp. 400-13.

OOSTINDIE, GERT J., 2006. Dependence and Autonomy in Sub-national Island Jurisdictions: The Case of the Kingdom of the Netherlands. The Round Table-The Commonwealth Journal of International Affairs 95(386):609-26.

—, \& Inge Klinkers, 2003. Decolonising the Caribbean: Dutch Policies in a Comparative Perspective. Amsterdam: Amsterdam University Press.

PURI, SHALINI, 2003. Marginal Migrations: The Circulation of Cultures within the Caribbean. Oxford: MacMillan.

—, 2004. The Caribbean Postcolonial: Social Equality, Post-Nationalism, and Cultural Hybridity. New York: Palgrave MacMillan.

REY, ALAIN (ed.), 2000. Le Robert - Dictionnaire historique de la langue française. 3 vols. Paris: Dictionnaires Le Robert. [Orig. 1992.]

Rodier, Claire, 1999. Les entorses au principe d'assimilation. Plein Droit 43:9-10.

ROlland, Louis \& PierRe LAMPuÉ, 1949. Précis de droit des pays d'outremer et de la coopération. Paris: Dalloz.

SAMSON, MIKE L., 1989. The Netherlands Antilles. In Robert B. Potter (ed.), Urbanization, Planning and Development in the Caribbean. London: Mansell, pp. 161-80.

SANGUIN, ANDRÉ-LOUIS, 1982. Saint-Martin, les mutations d'une île franco-néerlandaise dans les Antilles. Cahiers d'Outre-Mer 35(138):123-40.

SPENER, DAVID \& KATHLEEN A. STAUDT (eds.), 1998. The U.S.-Mexico Border: Transcending Divisions, Contesting Identities. Boulder CO: Lynne Rienner.

SPIRE, ALEXIS, 1999. De l'étranger à l'immigré. La magie sociale d'une catégorie statistique. Actes de la Recherche en Sciences Sociales 129:50-56.

St. JACQUES, ERMITTE, 2001. "Today Haitians, Tomorrow Bahamians": Reassessing the Integration of Haitian Immigrants in the Bahamas. MA Thesis, University of Florida, Gainesville.

TAGLIONI, FRANÇOIS, 2005. Les revendications séparatistes et autonomistes au sein des États et territoires mono- et multi-insulaires: Essai de typologie. Cahiers de géographie du Québec 49(136):5-18.

TERRAY, EMMANUEL, 2006. 1942-2006: Réflexions sur un parallèle contesté. Paris: Centre d'études et d'initiatives de solidarité internationale. http://www.reseau-ipam.org/article. php3?id_article=1278\#.

Thomas, Robert N., Bruce WM. Pigozzi \& Richard Alan SAmbrock, 2005. Tourist Carrying Capacity Measures: Crowding Syndrome in the Caribbean. The Professional Geographer 57(1):13-20. 
TsouKala, ANASTASSIA, 2005. Looking at Migrants as Enemies. In Didier Bigo \& Elspeth Guild (eds.), Controlling Frontiers: Free Movement into and within Europe. Hants, U.K.: Ashgate, pp. 161-92.

UNI-E-S CONTRE UNE IMMIGRATION JETABLE, 2007. Contre-rapport sur immigration et droit d'asile. Paris: Uni-e-s contre une immigration jetable.

VILA, PABLO (ed.), 2003. Ethnography at the Border. Minneapolis: University of Minnesota Press.

WANG, HoRNG-LUEN, 2004. Regulating Transnational Flows of People: An Institutional Analysis of Passports and Visas as a Regime of Mobility. Identities: Global Studies in Culture and Power 11(3):351-76.

WiLsOn, THOMAS M. \& DONNAN HASTINGS (eds.), 1998. Border Identities: Nation and State at International Frontiers. Cambridge: Cambridge University Press.

CATHERINE BENOÎT

Department of Anthropology

Connecticut College

New London CT 06320, U.S.A.

<catherinebenoit@mac.com> 